\title{
O crack, o pai e os psiquiatras e psicanalistas
}

\author{
Crack, the father, psychiatrists and psychoanalysts
} \begin{abstract}
Sérgio de Paula Ramos*
* Psiquiatra e psicanalista. Coordenador da Unidade de Dependência Química do Hospital Mãe de Deus, Porto Alegre, RS. Membro do Conselho
\end{abstract}

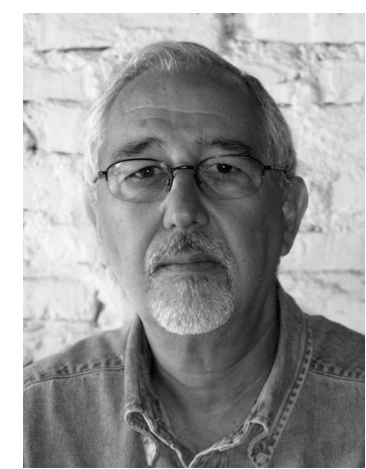
Consultivo da Associação Brasileira de Estudos sobre o Álcool e Outras Drogas (ABEAD). E-mail: serramos@terra.com.br

Nos últimos 20 anos, diferentes pesquisadores demonstraram um crescente consumo de todas as drogas de abuso por parte de estudantes, no Brasil e em Porto Alegre. Nos mais recentes desses levantamentos, também ficou evidente uma tendência de o padrão de consumo das moças se igualarem ao dos rapazes. Embora não disponhamos de séries históricas com adultos, a clínica nos sinaliza que o consumo de álcool se manteve estável, o de tabaco decresceu, mas o das demais drogas aumentou, notadamente o dos estimulantes, e neste momento estamos vivendo uma epidemia de uso de crack. Apesar de seus usuários serem, na maioria, jovens, já se constata casos entre crianças e adultos de todos os segmentos econômicos.

O fenômeno é complexo e, para entendê-lo, teremos que nos socorrer da antropologia, da sociologia, da genética, da psiquiatria e da psicologia. No presente texto, ocupar-me-ei da contribuição que a psicanálise pode dar, não só para ampliar sua compreensão como também para sugerir medidas de prevenção.

No final dos anos 80, tínhamos uma epidemia de uso injetável de cocaína. Os pacientes se expunham a todos os riscos conhecidos para obter o prazer químico. Aliás, ficou evidente naquela época que se tratava de dois tipos de prazeres. O do efeito farmacológico da droga, claro, mas também, ao se injetar, o prazer quase orgástico de aspirar seu sangue para o êmbolo da seringa e com isso poder visualizá-lo. Além disso, esses pacientes, quando conseguiam abster-se da droga, relatavam insistentemente um sentimento de vazio intenso a lhes engatilhar episódios de "fissura" por novo consumo.

Gostaria, neste momento, de destacar estes dois aspectos relevantes: o prazer na visualização do próprio sangue e o sentimento quase oceânico de vazio. O que a psicanálise foi capaz de descobrir é que, por um lado, existem diferentes tipos de dependentes químicos, e por outro, não existe uma problemática ou conflitiva, se preferirem - universal a todos. No entanto, esses pacientes que eram dependentes de droga injetável apresentavam o prazer na visualização de seu sangue e o sentimento de vazio. Para ter o primeiro e evitar o segundo, assumiam riscos de toda ordem, a ponto de serem descritos na literatura como tendo risk taking behavior, caracterizado pelo prazer em expor sua vida.

A clínica psicanalítica nos ensinou que esse subtipo de dependente de drogas sofreu um acentuado comprometimento na internalização de seus objetos primitivos, e o cenário habitual são pessoas simbiotizadas com suas mães, percebidas de forma extremamente fragmentada, e com a figura do pai periférica. Como os estudos prospectivos estão a nos sinalizar que, para entender a dependência química, na adolescência, é necessário em cada caso responder à pergunta "onde está o pai?", parece que a situação descrita deve-se mais ao comprometimento da função paterna na alavancagem para que ocorra o término da simbiose. Por este vértice, o que esses pacientes necessitam é, então, a restauração dessa função paterna.

A pergunta atual é se o tipo de paciente que está se envolvendo com crack é semelhante àquele, do passado, com droga injetável. Em comum, têm o risco sério e a prática do que chamarei de "quase morte para me descobrir vivo". De fato, os comportamentos de risco e a visualização do sangue parecem atender a um desiderato de que "se não morri é porque estou vivo". Igualmente, "se vejo meu sangue, idem, idem".

Tais pacientes apresentam freqüente comorbidade de eixo II, com diagnósticos do cluster $\mathrm{B}$, e, para eles, a sensação de estar vivo dá-se pela não-morte.

O que penso é que, sem desprezar as contribuições de outras áreas do conhecimento, podemos constatar algum sentido nas hipóteses acima quando percebemos que, nas áreas pobres, onde se iniciou a atual epidemia, 
vive-se uma total ausência concreta de pai, e nas classes média e rica, para onde a epidemia está se espraiando, o movimento ocorre às custas de famílias onde a dita função paterna está, em regra, comprometida.

Com base nesses achados, o que se pode propor? Concretamente, mais pai. Aliás, quando a cidade de Nova Iorque o teve na figura do prefeito Giuliani, despencou o consumo de drogas e a criminalidade dele decorrente. E entre nós? Bem, vivemos um momento especial com a implementação do programa
"Tolerância Zero no Trânsito". Em 1 mês, tivemos $63 \%$ de mortes a menos! Em minha vida, não tinha ainda visto tamanho impacto epidemiológico determinado por uma lei. Baseado nisso, sugiro que nós, psiquiatras e psicanalistas, divulguemos mais nossos pontos de vista e favoreçamos o reforço da função paterna em todos os níveis - na família, na escola, nas ruas, no Estado, tanto através do trabalho em nossos consultórios, o que sempre fizemos, como na comunidade. A meu juízo, estaremos contribuindo para o enfrentamento da atual epidemia. 